\title{
PERLINDUNGAN HUKUM TERHADAP KONSUMEN DALAM SISTEM TRANSAKSI ONLINE PERSPEKTIF UNDANG-UNDANG INFORMASI DAN TRANSAKSI ELEKTRONIK
}

\author{
Rizka, M. Zaki Attirmidzi; Universitas Muhammadiyah Surakarta, EduShallman Jl. KS Tubun \\ No. 18 Manahan Banjarsari Kota Surakarta Jawa Tengah 57139; E-mail: rizka@ums.ac.id
}

\begin{abstract}
Abstrak
Penelitian yang membahas bagaimana perlindungan hukum terhadap konsumen dalam jual beli online dan bagaimana tanggung jawab pelaku usaha terhadap perlindungan konsumen dalam jual beli online ini, menggunakan metode pendekatan yuridis-normatif dengan data sekunder sebagai sumber data utamanya. Dari penelitian ini diperoleh hasil penelitian bahwa perlindungan hukum terhadap konsumen dalam jual beli online diatur di dalam Undang-Undang Nomor 8 Tahun 1999 tentang Perlindungan Konsumen, Undang-Undang Nomor 19 Tahun 2016 tentang Perubahan Atas Undang-Undang Nomor 8 Tahun 2011 tentang Informasi dan Transaksi Elektronik, serta Peraturan Pemerintah Nomor 71 Tahun 2019 tentang Penyelenggaraan Sistem dan Transaksi Elektronik. Pada prinsipnya pelaku usaha dapat dituntut pertanggungjawaban dalam transaksi online lewat pertanggungjawaban kontraktual prinsip tanggung jawab berdasarkan unsus kesalahan, prinsip praduga untuk selalu bertanggung jawab, prinsip tanggung jawab mutlak.
\end{abstract}

Kata Kunci: Perlindungan Hukum, Pelaku Usaha, Konsumen, Transaksi Online

\begin{abstract}
This study discusses how the legal protection for consumers in online buying and selling and how the responsibility of business actors towards consumer protection in online buying and selling uses a juridicalnormative approach with secondary data as the main data source. From this study, it found that legal protection for consumers in online buying and selling is regulated by Law Number 8 of 1999 concerning Consumer Protection, Law Number 19 of 2016 concerning Amendments to Law Number 8 of 2011 concerning Information and Transactions Electronics, and Government Regulation Number 71 of 2019 concerning the Implementation of Electronic Systems and Transactions. In principle, business actors can be held accountable in online transactions through contractual accountability, the principle of responsibility based on the element of error, the principle of presumption of being responsible, and the principle of absolute responsibility.
\end{abstract}

Keywords: Legal Protection, Business Actors, Consumers, Online Transactions

\section{PENDAHULUAN}

\section{Latar Belakang}

Dewasa ini tidak ada kegiatan manusia modern yang lepas dari teknologi yang dapat membantu dalam menyelesaikan tugas-tugasnya secara cepat dan efisien. ${ }^{1}$ Salah satu perkembangan komunikasi saat ini yang pesat adalah internet. Internet sebagai suatu media informasi dan komunikasi elektronik telah banyak dimanfaatkan untuk berbagai kegiatan, antara lain untuk perdagangan. ${ }^{2}$ Pada awalnya perdagangan dilakukan dengan

\footnotetext{
${ }^{1}$ Erie Hariyanto. (2012). "Perlindungan Hukum Transaksi Jual Beli Komputer Rakitan Menurut Undang-Undang tentang Perlindungan Konsumen (Studi di Bintan Risky Computer Surabaya)". Vol. 12, No. 3, Jurnal Dinamika Hukum, h. 391.

2 Fitriah. (2020). "Perlindungan Hukum bagi Konsumen dalam Transaksi Jual Beli melalui Media Sosial". Vol. 18, No. 3, Jurnal Unpal, h. 31.
} 
cara konvensional, yaitu dengan bertemunya penjual dan pembeli untuk melakukan transaksi jual beli. Namun seiring perkembangan teknologi, pasar sebagai tempat bertemunya permintaan dan penjualan mengalami perubahan. Pembeli dan penjual tidak lagi harus bertatap muka untuk melakukan transaksinya, munculnya internet sebagai media baru mendorong perubahan ini menjadi lebih maju, kecepatan, kemudahan serta murahnya biaya internet menjadi pertimbangan banyak orang untuk memakainya termasuk melakukan transaksi. ${ }^{3}$

E-commerce memiliki karakternya tersendiri dalam dunia perdagangan. Hal tersebut seperti luasnya jarak yang tidak mengharuskan pihak yang terlibat bertemu secara langsung dan piak yang terlibat tidak diharuskan untuk melakukan transaksi secara langsung. ${ }^{4}$ E-commerce mempunyai dua bagian yaitu terdiri antara pelaku usaha dan perdagangan antar pelaku usaha dengan pembeli atau konsumen. ${ }^{5}$ Kegiatan transaksi jual beli semakin dituntut untuk terkoneksi dengan media internet. Seperti halnya, semakin banyaknya usaha dagang yang mengandalkan internet sebagai media transaksi. Tidak heran banyak masyarakat yang mengandalkan sistem online sebagai media pembayaran, karena masyarakat bisa lebih leluasa untuk memilih produk seperti barang atau bisa juga jasa, serta untuk memilih produk dengan kuantitas serta kualitas yang bagus melalui internet. ${ }^{6}$

Ada beberapa faktor yang mempengarugi perkembangan transaksi online yaitu: 1) Ecommerce memiliki kemampuan untuk menjagkau lebih banyak pelanggan dan setiap saat informasinya dapat diakses secara up to date dan terus menerus; 2) mendorong kreativitas dari pihak penjual secara cepat dan tepat dalam pendistribusian informasi yang disampaikan secara periodik; 3) dapat menciptakan efisiensi waktu yang tinggi, murah dan informatif; 4) dapat meningkatakn kepuasan pelanggan, dengan pelayanan cepat, mudah, aman, dan akurat. Pada dasarnya pihak-pihak dalam jual beli online, masing-masing pihak memiliki hak dan kewajiban. Penjual merupakan pihak yang menawarkan produk melalui internet, oleh karena itu seorang penjual wajib memberikan informasi secara benar dan jujur atas produk yang ditawarkan oleh konsumen. Pelaku usaha memiliki hak untuk mendapatkan pembayaran dari konsumen atas barang yang dijualnya, juga berhak untuk mendapatkan perlindungan atas tindakan konsumen yang beritidak tidak baik dalam melaksanakan transaksi jual beli secara transaksi online. ${ }^{7}$

Namun transaksi online ini juga memiliki beberapa kelemahan. Dengan menggunakan transaksi online yang tidak mempertemukan antara yang memiliki usaha

\footnotetext{
${ }^{3}$ Imam, Sjaputra. (2002). Problematika Hukum Internet Indonesia. Jakarta: Prehnhallindo, h. 92.

${ }^{4}$ Bama Anandika Berata, Bagus Made. (2016). "Perlindungan Hukum terhadap Pelaku Usaha Terkait Wanprestasi yang Dilakukan Konsumen dengan Cara Hit and Run". Kertha Samaya: Jurnal Ilmu Hukum, Vol. 4, No. 3, 2016.

${ }^{5}$ Riyeke Ustadiyanto. (2001). Framework E-Commerce. Yogyakarta: ANDI, h. 138.

6 Ida Ayu Eka Pradnyaswari, I Ketut Westra. (2020). "Upaya Perlindungan Hukum bagi Konsumen dalam Transaksi Jual Beli Menggunakan Jasa E-Commerce". Vol. 8, No. 5, 2020, Jurnal Kertha Semaya, h. 759.

7 Aan Handriani. (2020). "Perlindungan Konsumen dalam Perjanjian Transaksi Jual Beli Online". Vol. 3, No. 2, Pamulang Law Review, h. 128.
} 
online dan pembeli langsung dan dimana konsumen tidak dapat melihat barang yang diinginkan secara nyata (dalam wujud dan kondisi yang sebenarnya) hal ini dapat menimbulkan masalah yang merugikan pembeli dalam melakukan transaksi online. Contoh adalah ketidaksesuaian barang yang dijanjikan, tidak tepatnya waktu pengiriman barang. ${ }^{8}$ Fenomena transaksi online membuat kedudukan antara pelaku usaha dan konsumen tidak seimbang, konsumen seringkali berada di posisi yang lemah dan lebih banyak dirugikan karena menjadi objek bisnis bagi pelaku usaha yang money oriented semata sehingga mengesampingkan kualitas prosuk dan kepuasan konsumen. Meskipun terdapat risiko dan kerugian yang mungkin akan terus terjadi, kegiatan transaki online tidak mungkin dihindari apalagi dengan dinamika perkembangan teknologi yang kini semakin canggih. Pasar jual beli online juga sudah menjadi salah satu strategi marketing utama di dunia termasuk di Indoneisa. ${ }^{9}$

Perkembangan transaksi online ini menimbulkan permasalahan baru di bidang hukum, khususnya di bidang hukum perlindungan konsumen. Dalam lingkup pembicaraan hukum dan teknologi, perlindungan hukum konsumen menjadi hal yang sangat efektivitas perkembangan dan penerapan teknologi tersebut di tengah masyarakat. ${ }^{10}$ Maka dengan adanya perlindungan hukum tersebut dimaksudkan sebagai upaya untuk menjamin kepastian hukum dan dapat melindungi konsumen. Berbagai hal negatif akibat konsumsi produk baik barang maupun jasa harus disingkirkan dari perdangangan sebab itulah tujuan dari perlindungan konsumen.11 Untuk itu diperlukan aturan dan kepastian hukum yang dapat menjamin perlindungan hukum bagi konsumen yang menjadi pihak yang paling dirugikan dalam transaksi jual beli online.

\section{Rumusan Masalah}

Adapun rumusan masalah dalam karya ilmiah ini adalah:

1. Bagaimana perlindungan hukum terhadap konsumen dalam jual beli online?

2. Bagaimana tanggung jawab pelaku usaha terhadap perlindungan konsumen dalam jual beli online?

\section{METODE PENELITIAN}

Penelitian ini merupakan penelitan yuridis-normatif,12 yakni penelitian yang secara doktrinal meneliti aturan dasar dan perundang-undangan mengenai masalah masalah yang dihadapi dalam perlindungan hukum terhadap konsumen dalam transaksi jual beli online. Melalui penelitian ini diharapkan dapat diketahui berbagai permasalahan yang berkembang dan faktor-faktor yang mempengaruhinya.

\footnotetext{
8 I Putu Erick Sanjaya Putra, I Nyoman Putu Budiartha, Ni Made Sukayarti Karma. (2019). "Perlindungan Hukum terhadap Konsumen dalam Jual Beli Barang Melalui E-Commerce". Vol. 1, No. 2, Jurnal Analogi Hukum, h. 240.

${ }^{9}$ Atika Rahmadanty, Madani Masaputri Wijayanto. Op.Cit., h. 2.

10 Edmon Makarim. (2005). Pengantar Hukum Telematika Suatu Kompilasi Kajian. Jakarta: Rajagrafindo Persada, h. 25.

11 Wedari, Sayu Surya Ayu. (2018). "Perlindungan Konsumen terhadap Penyalahgunaan Obat

Dekstrometordan di Indonesia. Vol. 5, No. 1, Kertha Sanjaya: Jurnal Ilmu Hukum, h. 760.

${ }^{12}$ Soerjono Soekanto. (2004). Penelitian Hukum Normatif. Jakarta: PT. Raja Grafindo, h. 14.
} 
Jenis Penelitian ini dapat juga disebut penelitian deskriptif analitis dalam arti bahwa hasil penelitian ini disajikan secara deskriptif analitis. Jadi jenis penelitian ini dipilih sebagai cara penyajian dan bukan pokok penelitian itu sendiri. Dalam penggunaan data, terdapat 2 jenis data yang dipakai dalam penelitian ini yaitu data primer dan data sekunder. Data primer adalah data yang diperoleh langsung dari lapangan berdasarkan wawancara dengan responden atau berdasarkan observasi atas masalah yang diteliti. Sedangkan data sekunder adalah data yang diperoleh dari bahan-bahan tertulis antara lain mencakup dokumen-dokumen resmi, buku-buku, hasil-hasil penelitian yang berwujud laporan, buku harian, dan lain-lain. ${ }^{13}$ Sebagaimana penelitian hukum pada umumnya, penelitian ini lebih bertumpu pada data sekunder yakni bahan-bahan tertulis tentang hukum. Berdasarkan hal tersebut maka jenis data di dalam penelitian ini terdiri dari: data sekunder, yakni bahan-bahan hukum yang tersebar dalam berbagai tulisan yang dibedakan atas: ${ }^{14}$

1. Bahan hukum primer, yang terdiri dari peraturan perundang-undangan dan peraturan peraturan lainnya yang terkait mengenai perlindungan konsumen.

2. Bahan hukum sekunder, yakni bahan-bahan hukum berupa tulisan-tulisan hukum yang berbentuk buku, makalah, artikel.

3. Bahan hukum tersier, yakni bahan-bahan hukum yang berisi penjelasan arti tentang berbagai istilah yang terkait dengan objek penelitian seperti kamus bahasa, kamus hukum, kamus politik, dan ensiklopedia.

Jenis-jenis data yang disebutkan diatas dikumpulkan melalui cara dengan studi kepustakaan, yakni studi atas berbagai data sekunder atau dokumen, baik terhadap bahan hukum pimer, sekunder, maupun tersier dan diklasifikasi berdasarkan materinya masing-masing.

\section{PEMBAHASAN}

\section{A. Perlindungan Hukum terhadap Konsumen dalam Jual Beli Online}

Kegiatan jual beli secara online merupakan cara baru yang cukup berkembang saat ini, sebab dapat memudahkan konsumen dalam memenuhi kebutuhan berbelanja. Transaksi online menjadi pilihan karena memiliki keunggulan antara lain lebih praktis serta mudah dan dapat dilakukan kapanpun selama memiliki koneksi internet, namun disisi lain memiliki dampak negatif yaitu timbulna permasalahan hukum yang dapat menimbulkan kerugian bagi konsumen. ${ }^{15}$ Kemungkinan terjadinya kasus penipuan juga begitu besar, disebabkan oleh kurangnya informasi yang seringkali diterima oleh konsumen. Walaupun secara keabsahan proses transaksi sudah dijelaskan pada Kitab Undang-Undang Hukum Perdata (KUHPerdata) pada Pasal 1458 yang menyebutkan: "Jual beli dianggap telah terjadi antara kedua belah pihak, seketika setelahnya orang-orang ini

\footnotetext{
${ }^{13}$ Soerjono Soekanto. (1986). Pengantar Penelitian Hukum. Jakarta: UI-Pers, h. 12.

${ }^{14}$ Soerjono Soekanto \& Sri Mamudji. (2001). Penelitian Hukum Normative: Suatu Tinjauan Singkat, Edisi 1, Cet. V, Jakarta: PT Raja Grafindo Persada, h. 29.

15 Neni Sri Imaniyati, Husni Syawali. (2000). Hukum Perlindungan Konsumen. Bandung: Mandar Maju.
} 
mencapai kata sepakat tentang kebendaan tersebut dan harganya, maupun harganya belum dibayar". Jelas ini menjadi pekerjaan tambahan untuk memberi rasa nyaman untuk kedua belah pihak baik pelaku usaha maupun konsumen. Oleh karena itu, maka keperluan adanya perlindungan hukum bagi konsumen yang melakukan transaksi online sangat diperlukan terutama karena konsumen memiliki hak secara universal harus dilindungi yakni hak atas keamanan dan keselamatan serta hak informasi yang benar.

Di dalam Undang-Undang Nomor 8 Tahun 1999 tentang Perlindungan Konsumen (UUPK) belum dapat melindungi konsumen dalam transaksi secara online karena ketentuan-ketentuan yang tercantum dalam UUPK belum mengakomodir hak-hak konsumen dalam transaksi online. Hal tersebut dikarenakan transaksi online mempunyai karakteristik tersrbut adalah tidak bertemunya penjual dan pembeli, media yang digunakan adalah internet, transaksi dapat terjadi melintasi batas-batas yuridis suatu negara, barang diperjualbelikan dapat berupa barang atau jasa digital seperti software. ${ }^{16}$

Hak hak konsumen di Indonesia diakomodir dalam Pasal 4 UUPK yaitu 1) hak atas kenayaman, keamanan, dan keselamatan dalam mengkonsumsi barang dan/atau jasa; 2) hak untuk memilih barang dan/atau jasa serta mendapatkan barang dan/atau jasa tersebut sesuai dengan nilai tukar dan kondisi serta jaminan yang dijanjikan; 3) hak atas informasi yang benar, jelas, dan jujur mengenai kondisi dan jaminan barang dan/atau jasa; 4) hak untuk didengar pendapat dan keluhannya atas barang dan/atau jasa yang digunakan; 5) hak untuk mendapatkan advokasi perlindungan, dan upaya penyelesaian sengketa perlindungan konsumen secara patut; 6) hak untuk mendapatkan pembinaan dan pendidikan konsumen; 7) hak untuk diperlakukan atau dilayani secara benar dan jujur serta tidak diskriminatif; 8) hak untuk mendapatkan kompensasi, ganti rugi dan/atau penggantian, apabila barang dan/atau jasa yang diterima tidak dengan perjanjian atau tidak sebagaimana mestinya; 9) hak-hak yang diatur dalam ketentuan peraturan perundang-undnagan lainnya. Kemudian kaitannya dengan hak konsumen sebagaimana yang terdapat dalam Pasal 4 huruf c UUPK bahwa konsumen berhak mendapatkan informasi yang benar dan jelas mengenai produk yang dijual oleh pelaku usaha, maka dalam Undang-Undang No. 19 Tahun 2016 tentang Perubahan atas UndangUndang Nomor 11 Tahun 2008 tentang Informasi Transaksi dan Elektronik diatur mengenai hal tersebut yang terdapat dalam Pasal 9 UU ITE yaitu "Pelaku usaha yang menawarkan produk melalui sistem elektronik harus menyediakan informasi yang lengkap dan benar berkaitan dengan syarat kontrak, produsen, dan produk yang ditawarkan". Ketentuan yang terdapat dalam Pasal 9 UU ITE tersebut tentunya memberikan kepada konsumen hak untuk mendapatkan suatu informasi yang benar dan lengkap mengenai barang atau produk yang ditawarkan oleh pelaku usaha dalam melakukan kegiatan perdagangan melalui media elektronik. ${ }^{17}$ Perlindungan hukum bagi konsumen dalam transaksi online terdapat Pasal 28 ayat (1) UU ITE “Setiap orang dengan

16 Heldya Natalia Simanullang. (2017). "Perlindungan Hukum terhadap Konsumen dalam Transaksi E-Commerce". Vol. 1, No. 1, Melayunesia Law, h. 118.

17 Roberto Ranto. (2019). "Tinjauan Yuridis Perlindungan Hukum terhadap Konsumen dalam Transaksi Jual Beli melalui Media Elektronik". Jurnal Ilmu Hukum Aletha, Vol. 2, No. 2, h. 22. 
sengaja dan tanpa hak menyebarkan berita bohong dan menyesatkan yang mengakibatkan kerugian konsumen dalam transaksi elektronik" mengenai sanksi pidana dalam Pasal 28 ayat (1) ketentuannya terdapat dalam Pasal 45 a ayat (1) UU ITE yaitu"setiap orang yang dengan sengaja dan tanpa hak menyebarkan berita bohong dan menyesatkan yang mengakibatkan kerugian konsumen dalam transaksi elektronik sebagaimana dimaksud dalam Pasal 28 ayat (1) dipidana dengan pidana penjara paling lama 6 tahun dan/atau denda paling banyak Rp.1.000.000.000 satu milyar.

Keterbatasan UUPK untuk melindungi konsumen dalam bertransaksi secara online juga tampak terbatasnya ruang lingkup pengertian pelaku usaha. Pasal 1 ayat (3) UUPK yang dimaksud pelaku usaha adalah "setiap orang perseorangan atau badan usaha, baik yang berbentuk badan hukum maupun bukan badan hukum yang didirikan dan berkedudukan atau melakukan kegiatan dalam wilayah Indonesia, baik sendiri maupun bersama-sama melalui perjanjian menyelenggarakan kegiatan usaha dalam berbagai bidang ekonomi" sedangkan menurut penjelasan pasal 1 ayat (3) UUPK, yang termasuk dalam pelaku usaha adalah pelaku usaha yang termasuk dalam pengertian ini adalah perusahaan, korporasi, BUMN, koperasi, importir, pedagang, distributor, dan lain-lain.

Melihat pengertian di atas sangatlah sempit sekali pengertian pelaku usaha yang daitur oleh UUPK, dimana pelaku usaha yang diatur dalam UUPK adalah pelaku usaha yang wilayah kerjanya di wilayah Negara Republik Indonesia. Padahal jika dilihat dari karakteristik transaksi online, salah satunya adalah perdagangan yang melintasi batasbatas negara maka pengertian pelaku usaha dalam UUPK ini tidak dapat mengjangkau jika pelaku usaha tersebut tidak berada di wilayah Negara Republik Indonesia. Akan tetapi UUPK tetap masih menjangkau pelaku usaha toko online yang melakukan usahanya di wilayah Negara Republik Indonesia meskipun didalamnya tidak secara khusus mengatur transaksi online. Beberapa pasal yang dapat dijadikan pedoman dalam menyelesaikan kasus penipuan pada transaksi online adalah sebagai berikut:

1. Pasal 8 ayat (1) huruf $\mathrm{d}$, e, dan $\mathrm{f}$ yang menyebutkan bahwa pelaku usaha dilarang memproduksi dan/atau memperdagangkan barang dan/atau jasa yang tidak sesuai dengan mutu, kondisi maupun janji sebagaimana dinyatakan dalam label, keterangan, iklan maupun promosi penjualan barang dan/atau jasa tersebut.

2. Pasal 16 huruf a dan $b$ yang menyebutkan bahwa pelaku usaha dalam menawarkan barang dan/atau jasa melalui pesanan dilarang untuk tidak menepati pesanan dan/atau kesepaktakan waktu penyelesaian sesuai dengan yang dijanjikan serta dilarang untuk tidak menepati janji atas suatu pelayanan dan/atau prestasi.

Dengan menumbuhkan kesadaran pelaku usaha mengenai pentingnya perlindungan konsumen sehingga tumbuh sikap yang jujur dan bertanggung jawab dalam berusaha. Dalam hal ini disamping keberadaan UUPK, regulasi yang secara khusus mengatur tentang kegiatan jual beli online diperlikan karena tidak hanya dapat memberikan perlindungan bagi konsumen tetapi juga pelaku bisnis. ${ }^{18}$

${ }^{18}$ Aan Handriani. Op. Cit. 
Perlindungan hukum untuk konsumen terletak pada garansi berupa pengembalian atau penukaran barang jika barang yang diterima tidak sesuai dengan yang dipesan sebagaimana yang dijelaskan dalam Pasal 19 UUPK dalam hal ganti kerugian yang dilakukan oleh penjual kepada konsumen yang menyebutkan bahwa

"pelaku usaha bertanggung jawab memberikan ganti rugi atas kerusakan, pencemaran, dan atau kerugian konsumen akibat mengkonsumsi barang dan atau jasa yang dihasilkan atau diperdagangkan".

Kemudian dalam Peraturan Pemerintah Nomor 71 tahun 2019 tentang Penyelenggaraan Sistem dan Transaksi Elektronik (PP PSTE) tetap diakui sebagai transaksi elektronik yang dapat dipertanggungjawabkan. Menurut Pasal 48 ayat (3) PP PSTE setidaknya harus memuat hal-hal sebagai berikut: data identitas para pihak; objek dan spesifikasi; persyaratan transaksi elektronik; harga dan biaya; prosedur dalam hal terdapat pembatalan oleh para pihak; ketentuan yang memberikan hak kepada pihak yang dirugikan untuk dapat mengembalikan barang dan/atau meminta penggantian produk jika terdapat cacat tersembunyi; dan pilihan hukum penyelesaian transaksi elektronik. Dengan demikian, pada transaksi elektronik yang terjadi dikasus dapat menggunakan instrumen PP PSTE sebagai dasar hukum dalam menyelesaikan permasalahannya.

\section{B. Tanggung Jawab Pelaku Usaha terhadap Konsumen dalam Jual Beli Online}

Undang-Undang Nomor 8 Tahun 1999 tentang Perlindungan Konsumen (UUPK) telah mengatur tentang tanggung jawab pelaku usaha dalam perjanjian jual beli dengan konsumen. Pasal 24 UUPK menyatakan:

"pelaku usaha yang menjual barang dan/atau jasa kepada pelaku usaha lain bertanggungjawab atas tuntutan ganti rugi dan/atau gugatan konsumen apabila:

1) Pelaku usaha lain menjual kepada konsumen tanpa melakukan perubahan apapun atas barang dan/atau jasa tersebut

2) Pelaku usaha lain, di dalam transaksi jual beli tidak mengetahui adanya perubahan barang dan/atau jasa yang dilakukan oleh pelaku usaha tau tidak sesuai dengan contoh, mutu, dan komposisi."

Tanggung jawab pelaku usaha menurut Gunawan Wijaya selalu berkaitan dengan kerugian yang dialami konsumen, termasuk dalam perjanjian jual beli di dalam hukum perlindungan konsumen tanggung jawab pelaku usaha dikenal dengan istilah product liability ${ }^{19}$ perkembangan akibat globalisasi perdagangan dunia dan kemajuan teknologi, memunculkan sistem jual beli melalu online (e-commerce). E-commerce bukan hanya perdagangan yang dilakukan melalui online saja sebagaimana dipahami banyak orang selama ini, melainkan pula meliputi setiap aktifitas perdaganan yang dilakukan atau menggunakan media elektronik lainnya. Transaksi online menghubungkan pelaku usaha, konsumen dan komunitas lainnya melalui transaksi elektronik untuk melakukan perdagangan barang, jasa dan informasi lainnya. Kondisi seperti ini menyebabkan jarak bukan lagi hambatan dalam dunia bisnis. Perkembangan menyolok teknologi internet membuat suatu produk dapat dipasarkan secara global dalam situs web, sehingga setiap

19 Gunawan Widjaja, Ahmad Yani. (2003). Hukum tentang Perlindungan Konsumen. Jakarta: Gramedia Pustaka Utama, h. 59. 
orang dimanapun dapat langsung mengakses situs tersebut untuk melakukan transaksi online. ${ }^{20}$

Keunikan pengaturan tentang transaksi online yaitu pelaku usaha dan konsumen tidak berhubungan secara langsung dan tidak membuat kesepakatan secara langsung. Aspek ini merupakan kelemahan terutama apabila salah satu pihak melakukan wanprestasi dan mengabaikan hak-hak konsumen sebagaimana diatur dalam UUPK. Dalam tanggung gugat berdasarkan adanya wanprestasi, kewajiban untuk mengganti kerugian tersebut akibat penerapan klausula dalam perjanjian merupakan ketentuan hukum yang dibuat oleh kedua belah pihak. Dengan demikian bukanlah Undangundang yang menentukan pembayaran ganti rugi dan berapa besar ganti rugi melainkan kedua belah pihak yang menentukan semuanya dalam perjanjian. Apa yang diperjanjikan tersebut mengikat sebagai Undang-Undang bagi mereka yang membuatnya. Pertanggungjawaban kontraktual adalah tanggung jawab perdata atas dasar perjanjian dari pelaku usaha (baik barang maupun jasa) atas kerugian yang dialami konsumen. Di dalam pertanggung jawaban kontrak terdapat suatu perjanjian antara pelaku usaha dengan konsumen.

Sebagaimana diketahui pasal 19 yang dimaksud mengatur tanggung jawab ganti rugi, pasal 22 tentang tanggung jawab pembuktian unsur kesalahan dalam perkara pidana, dan pasal 23 UUPK mengatur gugatan melalui Badan Penyelesaian Sengketa konsumen atau Badan Peradilan di tempat kedudukan konsumen, maka berdasarkan ketentuan Pasal 28 ini bahwa beban pembuktian unsur "kesalahan" dalam gugatan ganti rugi kerugian merupakan beban dan tanggung jawab pelaku usaha. Hal ini memeriksa konsekuensi hukum bahwa pelaku usaha yang dapat membuktikan kerugian bukan merupakan kesalahannya terbebas dari tanggung jawab kerugian. Sehubungan dengan pertanggungjawaban dalam transaksi online pelaku usaha tetap dapat dituntut pertanggungjawaban, apalagi jiak produk yang ditransaksikan itu cacat dan merugikan konsumen. Pelaku usaha yang menawarkan produk yang disjual kepada konsumen harus menyediakan informasi yang lengkap, jelas, dan benar hal ini untuk mengantisipasi ketika adanya kesalahan dalam bertransaksi. ${ }^{21}$

Secara umum prinsip-prinsip tanggung jawab dalam hukum perlindungan konsumen dapat dibedakan menjadi:22

1) Prinsip tanggung jawab berdasarkan unsus kesalahan (fault liability or liability based on fault)

Prinsip ini adalah prinsip yang cukup umum berlaku dalam hukum pidana dan perdata. KUHPerdata, khususnya pasal 1365, Pasal 1366, dan Pasal 1367, prinsip ini dipegang teguh secara utuh. ${ }^{23}$ Prinsip ini menyatakan bahwa "seseorang baru dapat dimintakan pertanggungjawaban secara hukum jika ada unsur kesalahan yang

\footnotetext{
${ }^{20}$ Aan Handriani. Op. Cit, h. 129.

21 Ibid, h. 130.

${ }^{22}$ Celina Tri Siwi kristiyanti. (2008). Hukum Perlindungan Konsumen. Jakarta: Sinar Grafika, h. 92-98.

${ }^{23}$ Purwahid Patrick. (2004). Dasar-Dasar Hukum Perikatan (Perikatan yang Lahir dari Perjanjian dan

Undang-Undang). Bandung: Mandar Maju, h. 10.
} 
dilakukannya". Pasal 1365 KUHperdata, yang dikenal sebagai pasal perbuatan melawan hukum yakni mengharuskan terpenuhinya 4 unsur pokok yakni: 1) Adanya perbuatan melanggar hukum; 2) Adanya unsur kesalahan; 3) Adanya kerugian yang diderita; 4) Adanya hubungan kausalitas antara kesalahan dan kerugian.

2) Prinsip praduga untuk selalu bertanggung jawab (presumption of liability principle)

Prinsip ini menjelaskan bahwa tergugat selalu dianggap bertanggung jawab sampai dapat membuktikan bahwa tidak bersalah. Beban pembuktian pada prinsip ini ada pada pihak tergugat. Prinsip ini diberlakukan beban pembuktian terbalik. Dasar pemikiran dari teori pembalikan beban pembuktian adalah seseorang dianggap tidak bersalah sampai yang bersangkutan dapat membuktikan sebaliknya. Jika digunakan, teori ini dalam kasus perlindungan konsumen, maka yang berkewajiban untuk membuktikan kesalahan itu ada di pihak pelaku usaha yang digugat, tergugat ini yang harus menghadirkan bukti-bukti bahwa dirinya tidak bersalah. Posisi konsumen sebagai penggugat selalu terbuka untuk digugat balik oleh pelaku usaha, jika konsumen gagal menunjukkan kesalahan tergugat. Seseorang dianggap bersalah sampai yang bersangkutan dapat membuktikan sebaliknya, hal ini tentu bertentangan dengan asas hukum praduga tidak bersalah yang lazim dikenal dalam hukum namun jika diterapkan dalam kasus konsumen akan tampak asas ini cukup relevan karena yang berkewajiban untuk membuktikan kesalahan itu ada di pelaku. ${ }^{24}$

3) Prinsip tanggung jawab mutlak (strict liability)

Asas tanggung jawab ini dikenal dengan nama product liability. Tanggung jawab produk merupakan tanggung jawab produsen untuk produk yang dipasarkan kepada pemakai, yang menimbulkan dan menyebabkan kerugian karena cacat yang melekat pada produk tersebut. Prinsip ini dalam hukum perlindungan konsumen secara umum digunakan untuk menjerat pelaku usaha khususnya produsen barang yang memasarkan barang yang merugikan konsumen. Menurut prinsip ini, produsen wajib bertanggung jawab atas kerugian yang diderita oleh konsumen karena penggunaanya produk yang beredar di pasaran. Melalui prinsip ini, maka setiap konsumen yang merasa dirugikan akibat produk barang yang cacat atau tidak aman dapat menuntut kompensasi tanpa harus mempermasalahkan ada atau tidaknya unsur kesalahan di pihak produsen. ${ }^{25}$

Sehingga pada dasarnya konsep perlindungan hukum bagi konsumen itu meliputi dua hal, yaitu: Perlindungan hukum preventif dan perlindungan hukum represif. Menurut Philipus M. Hadjon, perlindungan hukum preventif adalah bentuk perlindungan hukum dimana rakyat diberi kesempatan untuk mengajukan keberatan atau pendapatnya sebelum suatu keputusan pemerintah mendapat bentuk yang administrasi.26 Dengan kata lain perlindungan hukum preventif merupakan perlindungan hukum bagi masyarakat yang bertujuan untuk mencegah terjadinya permasalahan atau sengketa. Maka dari itu sengketa dalam transaksi jual beli dengan

24 Celina Tri Siwi kristiyanti, Op. Cit., h. 95.

25 Shidarta. (2004). Hukum Perlindungan Konsumen. Jakarta: PT Grasindo, h. 80.

26 Philipus M. Hadjon. (1987). Perlindungan Hukum bagi Rakyat di Indonesia. PT. Bina Ilmu, h. 5. 
menggunakan media elektronik memerlukan pencegahan untuk memberikan perlindungan kepada konsumen. Sebagai bentuk pencegahan agar tidak terjadi kerugian kepada konsumen yaitu dengan cara pembinaan terhadap konsumen, dimana peran strategis pemerintah untuk melakukan perlindungan konsumen sebagaimana ditentukan dalam pasal 29 UUPK, dimaksudkan untuk membina konsumen dalam memperoleh haknya. Hal itu perlu dilakukan karena mengingat tingkat kesadaran konsumen akan haknya masih sangat rendah sebagai akibat dari tingkat pendidikan masyarakat di Indonesia yang umumnnya tertinggal. Oleh karena itu, pemerintah bekerja sama dengan Lembaga Perlindungan Konsumen Swadaya Masyarakat (LPKSM) berupaya melakukan pemberdayaan konsumen melalui pembinaan dan pendidikan konsumen. ${ }^{27}$ Kemudian ada perlindungan hukum yang bersifat represif yakni upaya hukum yang dilakukan untuk menyelesaikan permasalahan yang telah terjadi antara pelaku usaha dengan konsumen baik jalur litigasi maupun non litigasi yang sudah diatur didalam UUPK, UU ITE.

\section{PENUTUP}

Pengaturan mengenai perlindungan hukum terhadap konsumen dalam jual beli online dapat diberikan dari segi kepastian hukum yang tertuang didalam peraturan perundang-undangan seperti diatur di dalam Undang-Undang No. 8 Tahun 1999 tentang Perlindungan Konsumen, Undang-Undang Nomor 19 Tahun 2016 tentang Perubahan Atas Undang-Undang Nomor 11 Tahun 2008 tentang Informasi dan Transaksi Elektronik dan Peraturan Pemerintah Nomor 71 Tahun 2019 tentang Penyelenggaraan Sistem dan Transaksi Elektronik. Tanggung jawab bagi pelaku usaha dalam jual beli online adalah memberikan pelayanan, memberikan informasi produk yang dijual dengan jujur, jelas dan menjamin produk yang dijual sampai ke tangan pembeli dengan aman, termasuk juga memberikan kompensasi atau ganti rugi produk yang bermasalah. Pada prinsipnya pelaku usaha dapat dituntut pertanggungjawaban dalam transaksi online lewat pertanggungjawaban kontraktual prinsip tanggung jawab berdasarkan unsus kesalahan (fault liability or liability based on fault), prinsip praduga untuk selalu bertanggung jawab (presumption of liability principle), prinsip tanggung jawab mutlak (strict liability).

Perlunya melakukan revisi terhadap peraturan perundang-undangan khususnya UUPK seperti pengaturan secara detail mengenai transaksi online kemudian terkait pengertian di atas sangatlah sempit sekali pengertian pelaku usaha yang diatur oleh UUPK, dimana pelaku usaha yang diatur dalam UUPK adalah pelaku usaha yang wilayah kerjanya di wilayah Negara Republik Indonesia. Padahal jika dilihat dari karakteristik transaksi online, salah satunya adalah perdagangan yang melintasi batasbatas negara maka pengertian pelaku usaha dalam UUPK ini tidak dapat mengjangkau jika pelaku usaha tersebut tidak berada di wilayah Negara Republik Indonesia. Akan tetapi UUPK tetap masih menjangkau pelaku usaha toko online yang melakukan usahanya di wilayah Negara Republik Indonesia meskipun didalamnya tidak secara

${ }_{27}$ Dedi Harianto. (2010). Perlindungan Hukum Bagi Konsumen Terhadap Iklan yang Menyesatkan. Bogor: Ghalia Indonesia, h. 140-141. 
khusus mengatur transaksi online. Selain perlu mengatur secara detail. Perlunya pihak pemerintah bersama Lembaga Perlindungan Konsumen Swadaya Masyarakat (LPKSM) berupaya melakukan pemberdayaan konsumen melalui pembinaan dan pendidikan konsumen agar mereka selaku pembeli dapat selalu berhati-hati dalam melakukan transaksi online.

\section{DAFTAR PUSTAKA}

Aan Handriani. (2020). "Perlindungan Konsumen dalam Perjanjian Transaksi Jual Beli Online". Pamulang Law Review, Vol. 3, No. 2.

Ayu Eka Pradnyaswari, I Ketut Westra. (2020). "Upaya Perlindungan Hukum bagi Konsumen dalam Transaksi Jual Beli Menggunakan Jasa E-Commerce". Jurnal Kertha Semaya, Vol. 8, No. 5.

Bama Anandika Berata, Bagus Made. (2016). "Perlindungan Hukum terhadap Pelaku Usaha Terkait Wanprestasi yang Dilakukan Konsumen dengan Cara Hit and Run". Kertha Samaya: Jurnal Ilmu Hukum, Vol. 4, No. 3, 2016.

Celina Tri Siwi kristiyanti. (2008). Hukum Perlindungan Konsumen. Jakarta: Sinar Grafika.

Edmon Makarim. (2005). Pengantar Hukum Telematika Suatu Kompilasi Kajian. Jakarta: Rajagrafindo Persada.

Erie Hariyanto. (2012). “Perlindungan Hukum Transaksi Jual Beli Komputer Rakitan Menurut Undang-Undang tentang Perlindungan Konsumen (Studi di Bintan Risky Computer Surabaya)". Jurnal Dinamika Hukum, Vol. 12, No. 3.

Fitriah. (2020). "Perlindungan Hukum bagi Konsumen dalam Transaksi Jual Beli melalui Media Sosial". Jurnal Unpal, Vol. 18, No. 3.

Gunawan Widjaja, Ahmad Yani. (2003). Hukum tentang Perlindungan Konsumen. Jakarta: Gramedia Pustaka Utama.

Harianto. (2010). Perlindungan Hukum Bagi Konsumen Terhadap Iklan yang Menyesatkan. Bogor: Ghalia Indonesia.

Heldya Natalia Simanullang. (2017). "Perlindungan Hukum terhadap Konsumen dalam Transaksi E-Commerce". Melayunesia Law, Vol. 1, No. 1.

I Putu Erick Sanjaya Putra, I Nyoman Putu Budiartha, Ni Made Sukayarti Karma. (2019). "Perlindungan Hukum terhadap Konsumen dalam Jual Beli Barang Melalui ECommerce". Jurnal Analogi Hukum, Vol. 1, No. 2.

Imam, Sjaputra. (2002). Problematika Hukum Internet Indonesia. Jakarta: Prehnhallindo.

Neni Sri Imaniyati, Husni Syawali. (2000). Hukum Perlindungan Konsumen. Bandung: Mandar Maju.

Philipus M. Hadjon. (1987). Perlindungan Hukum bagi Rakyat di Indonesia. PT. Bina Ilmu.

Purwahid Patrick. (2004). Dasar-Dasar Hukum Perikatan (Perikatan yang Lahir dari Perjanjian dan Undang-Undang). Bandung: Mandar Maju.

Riyeke Ustadiyanto. (2001). Framework E-Commerce. Yogyakarta: ANDI.

Roberto Ranto. (2019). “Tinjauan Yuridis Perlindungan Hukum terhadap Konsumen dalam Transaksi Jual Beli melalui Media Elektronik". Jurnal Ilmu Hukum Aletha, Vol. 2, No. 2. 
Shidarta. (2004). Hukum Perlindungan Konsumen. Jakarta: PT Grasindo.

Soerjono Soekanto \& Sri Mamudji. (2001). Penelitian Hukum Normatif: Suatu Tinjauan Singkat, Edisi 1, Cet. V. Jakarta: PT Raja Grafindo Persada.

Soerjono Soekanto. (1986). Pengantar Penelitian Hukum. Jakarta: UI-Pers.

Soerjono Soekanto. (2004). Penelitian Hukum Normatif. Jakarta: PT. Raja Grafindo.

Wedari, Sayu Surya Ayu. (2018). "Perlindungan Konsumen terhadap Penyalahgunaan Obat Dekstrometordan di Indonesia. Kertha Sanjaya: Jurnal Ilmu Hukum, Vol. 5, No. 1. 